\title{
Sciendo
}

\section{Is Internet Access a Matter of Freedom of Expression? Some Examples from Ukraine}

\author{
Bogdan Kelichavyi \\ Shevchenko 64 \\ Kopychyntsi, Ternopil region 48260, Ukraine \\ E-mail: bogdan.kelichavyi@gmail.com \\ Katrin Nyman Metcalf \\ TalTech Law School, \\ Tallinn University of Technology \\ Akadeemia tee 3 , \\ Tallinn 12618, Estonia \\ E-mail: katrin.nyman-metcalf@taltech.ee
}

\begin{abstract}
Freedom of expression does not only mean absence of censorship or other restrictive content laws-it also means that people have real access to communication. Nowadays, internet is a key means of communication. In this article we explain the relevance of access to internet from legal, practical and market aspects for freedom of expression. To illustrate the question, we present the situation in Ukraine. We look at legislation, including restrictions due to national security-availability, affordability and accessibility of internet. Ukraine is an interesting example of a mixture of very positive indicators and some remaining restrictions.
\end{abstract}

Keywords: communications, freedom of expression, information technologies, internet, Ukraine 


\section{Introduction}

In many parts of the world, life without the internet is almost difficult to imagine. The internet has become much more than just a technology through which we can communicate or perform various private and public services - it is rather like the background against which we live large parts of our daily lives. The internet is the main medium that we use to interact with other individuals, enterprises or authorities, expressed in a more legalistic manner: it is a necessary tool for exercising freedom of expression.

Internet or cyberspace is an example of an area where legislation and regulation have rather played catch-up than dictated the ways of development. Had it been known or guessed when cyber-activities began just how important they would become; it is possible that legislators and regulators would not have permitted such a free development. We can only speculate what a potentially more intrusive regulatory action would have meant for the development of the internet and the related technologies, but cyberspace does appear as an example of how an absence of regulation can serve the interests of innovation. However, this same absence can become a problem once a technology is more mature, when there is a need for a secure environment for investment and competition.

The importance of freedom of expression for any country that aspires to be a democratic, rule-of-law state cannot be exaggerated. Freedom consists of both the right to express oneself and the right to have access to what others express - access to information. This means that freedom of expression does not just concern free media or debate but sets the stage for how public services are exercised and in what setting people can make decisions about their daily lives. In this context, it is clear that freedom of expression can contain many different elements and what exactly these elements are and how to protect them changes in time, as the means of communication change. Today, the internet is a key tool for freedom of expression and access to it is a prerequisite for exercising freedom.

The information and communications technology (ICT) sector is important for all countries, at whatever stage of development. It is seen as an engine of development that promotes positive change in almost any other sector of the economy. Access to good ICT needs protection by law and provision of physical possibilities to communicate. It is important for individuals but also for states, as different forms of communication contribute to building identity and economic viability of states (Schwarz, Satola \& Bustani, 2001, pp. 488-490). 
The situation for both freedom of expression in Ukraine and the development of communications infrastructure are complicated. There have been positive developments as well as negative ones-laws strengthening freedoms of communications and media as well as those restricting it. In the sphere of internet freedom, Ukraine is deemed "partly free" by the Freedom House survey (Freedom House, 2018). Ukraine is in the process of developing or perfecting various e-government services, which underlines the need for good internet access. In this article, we first analyse from a general and theoretical viewpoint why access to the internet is an essential feature of freedom of expression. The article does not only deal with the situation in Ukraine, but to show the theoretical questions in a practical setting we proceed with an analysis of the current situation in Ukraine. This provides a background to suggesting what reforms are needed in the country and how to achieve them, in order to use modern communications as a foundation for the development of the country in the economic sense as well as in the sense of strengthening the rule of law. The method used is analytical with aspects of action research in that practical suggestions are made. Sources used are legal and political science theoretical works, for the theoretical/analytical background, as well as statistics and current news reports for the section about the Ukrainian situation.

\section{Legal perspective on freedom of expression on the internet: a theoretical background}

The right to freedom of expression is protected by international law and further developed in the case-law. ${ }^{1}$ Not only is it an important freedom in its own right, but it is furthermore a prerequisite for the exercise of many other rights and freedoms. Many authors have discussed the question of the role of media for rule of law and democracy, from different angles. Habermas (1991) regards media as crucial in the transition to liberal democracy, creating a public sphere in which individuals can express themselves, discuss and argue, laying foundations for accountability and democracy. Media must be able to report on issues of societal relevance and have the tools for this. Media provides the information from which a public debate can arise (Harrison \& Woods, 2007).

Authors distinguish between layers of freedoms: for the communications infrastructure, for the communications market; and for content (Still, 2010,

1 Most importantly Article 19 of the Universal Covenant on Civil and Political Rights and Article 10 of the European Convention on Human Rights (ECHR). 
p. 330). At first glance, it may appear as if freedom of expression is best served by not having any restrictions at all, meaning no regulation pertaining to communication. However, a slightly deeper analysis soon shows that regulation is not only acceptable but even necessary in order for the communications landscape to function. The most obvious example is frequency regulation, as the frequency spectrum would not be of use to anyone if there were chaos and interference. The right to access to communication facilities is not expressed explicitly as a human right in international conventions or similar but is understood as an inherent feature that is expressed in specific rules such as on universal service obligation, frequency regulation, interoperability and similar (Still, 2010, p. 330). Regulation of communications-especially that which relates to content - can be a balance on what may appear as a thin line between forbidden censorship and legitimate regulation. There is a lot of interaction between various regulatory bodies (for infrastructure, frequencies, competition, content) and a mixture of legislation and other forms of instruments issued by regulatory organs. This makes for a complex regulatory environment in which to take into consideration the necessary practical developments, such as fastmoving technologies.

Communications regulation in Ukraine is based on the Law on Telecommunications of 2004 and it contains the same basic premises as in the European Union (EU), which includes an independent regulatory body: The National Commission for the State Regulation of Communications and Informatisation. This Commission was first set up in 2005 and in the current form established by a Presidential Decree dated November 23, 2011 (no. 1067/2011) based on the Law on Telecommunications. The body performs the normal functions of a regulator, but as in most situations of transition, it has had to defend its independence at times. The lack of transparency of the work of regulatory bodies has been an issue over the years. Such lack of transparency opens for the risk of "regulatory capture", when supposedly independent authorities instead become tools for certain interests (political or business interests) (Burlyuk, 2015, p. 5).

Regarding internet content, the ease with which people can spread such content to a global audience, without any "gatekeepers" in the form of editors, heads of broadcasting newsrooms, publishers or similar, means that this medium poses new questions about where the border should be between freedom and regulation. After a white supremacist terrorist outrage in New Zealand in March 2019 was live streamed on Facebook for many minutes before it was shut down, several countries have revealed plans to create legislation to make internet platforms responsible for faster action against such events, presumably leading to more restrictions on content to prevent the huge fines 
that could result in content not being removed fast enough. In Great Britain, in early April 2019, a proposal was made for a "duty of care" for internet platforms, to tackle illegal and harmful activities. Australia very rapidly adopted legislation with a similar aim immediately after the New Zealand event (The Economist, 2019). Although it is difficult to argue against the necessity to act to stop extremely harmful and extreme content, commentators are still worried about the possible chilling effect of such legislation, as the platforms may become overly restrictive if they fear huge sanctions (Access Now, 2019). On May 16, 2017, President of Ukraine Petro Poroshenko launched sanctions for three years against 81 largest Russian IT companies working in Ukraine (Decree no. 133/2017; Government of Ukraine, 2017b). The sanctions include the blocking of Ukrainian companies' assets, restrictions on trade operations, the prohibition of withdrawals outside Ukraine, the suspension of economic and financial obligations, and most importantly, blocking internet access providers from accessing these resources. Among other banned resources were social media networks that were highly popular in Ukraine, VKontakte $(V K)$ and Odnoklasniki, the search engine Yandex and mail service Mail.ru. Besides the negative economic implications against Russia, the official claim was regarding the security of personal data-Russian legislation allows its Federal Security Service (FSB) to get real-time data on all actions of users of Russian IT products.

When $V K$ was banned in 2017, millions of Ukrainian users lost access to their favourite social media platform. At a first glance, this may have looked like a generally unacceptable decision for a democratic country that tends to ensure human rights protection on its territory. However, Ukraine's avoidance of Russian internet services may have a legitimate reason to protect its own citizens that should also be taken into consideration. For instance, it is possible to illustrate the situation with the story about the founder of $V K$, Pavel Durov, who left his CEO post earlier in 2014 due to pressure from company shareholders and the Russian Federal Security Service. According to Durov, he was constantly asked to collaborate with the Russian government institutions including sharing personal information of Ukrainian Euromaidan protesters (Forbes Russia, 2014). When Pavel Durov successfully developed $V K$, he was informally called "a Russian Zuckerberg" and when he started refusing to give away users' personal data, the local media called him "a Russian Snowden". The story continues with Mr. Durov's next project, the messenger service Telegram, which has later been banned in Russia, the home country of the entrepreneur. In March 2018, the Russian Supreme Court recognised the legal requirement of the Federal Security Service to provide the keys to decrypt the Telegram's correspondence. On the same day, the Federal Service for Supervision of Communications, Information 
Technology and Mass Media (Roskomnadzor) notified Telegram of the need to fulfil the requirements of the law on providing information to the Federal Security Service of Russia. Telegram had 15 days to provide encryption keys for the FSB, after which it was blocked on the territory of the Russian Federation due to the refusal of Pavel Durov to provide the encryption keys to the FSB (The Bell, 2018). In the context of Ukraine banning Russian services, this leads to a difficult question: should a country ensure rights for free internet access if this leads directly to personal data exposure of its own citizens to a foreign regime?

\section{Legislation to provide access: global and European perspectives}

One of the tasks of the regulation is to ensure access to means of communicationtoday a key aspect is ensuring access to the internet. Having access to the internet on reasonable terms is a prerequisite for using modern means of communication and for being able to use different e-services, whether public e-governance or private services. This is so self-evident that it is sometimes almost forgotten both in the debate and in strategies and plans for increased use of e-services, but legislation as well as practical action ensuring internet access is essential when creating or strengthening the digital society. When so much of life takes place on the internet, including public services, the state has a responsibility for ensuring internet access of sufficient speed and quality at a reasonable price. Questions on providing real access are similar to the issue of the universal service obligation, which has been discussed by the European Court of Justice (CJEU) in several cases such as Corbeau [1991] and Altmark Trans GmbH... [2000]. The obligation is found in the sector-specific legislation that complements general competition law (De Muyter, 2012, pp. 453-454; Nikolinakos, 2006, p. 181).

ICT law, also called (electronic) communications law, aims to create the necessary conditions for promoting the development of electronic communications networks and services while ensuring the protection of the interests of users of such services. Legislation normally provides rules for how to enter the market, whether a licence or general authorisation is needed and, in that case, how it is obtained; what rules there are for service provision; and how monitoring and supervision are conducted. Sector specific legislation, such as communications law, to a large extent, includes ex-ante requirements and control, while general competition law to the most part is ex-post. Regulation should be as light as possible in a liberalised communications market, but it cannot be so light that it fails to provide minimum conditions. 
To prevent locking in users in the technology of today, which may have changed totally already tomorrow, regulation should be technology neutral (Communication COM(1999)539). The stipulations were made especially for telecommunications and, especially in the European Union, incorporated into the 2002 so-called telecommunications regulatory package, reformed in 2009. This does not guarantee that the concept is always well understood (Kamecke \& Körber, 2008, pp. 330-337). What it should mean is that rules should not prescribe specific technology but focus on results to be obtained. The principle is taken into consideration at different stages of rulemaking, in impact assessments and application. ${ }^{2}$

Traditionally, communications regulation used to be divided into categories for different types of communication. For messages transmitted from one known point (person) to another-point-to-point-such as telephone calls, letters or email, there is no reason for content regulation. If what is said is illegal based on any other law (planning a crime, libel and slander, incitement, and so on), it is very unlikely that the form of the message, the entity or technology used would be elements of the crime. For point-to-multipoint messages that can be seen or heard by an unknown audience, such as broadcasting or newspapers, it may be legitimate to have rules on content to prevent incitement, libel and slander or other content that is harmful for vulnerable groups. There may also be positive requirements, such as the need to broadcast news, make a distinction between opinions and facts as well as restrictions on specific things such as violence or pornography during certain hours. Internet falls between or above these categories: it can be point-to-point (e-mail, internet telephony) or pointto-multipoint (using internet as the transmission technology for broadcasting). Even more importantly, it can be something entirely different, multipoint-tomultipoint, with any number of possibilities for interaction, for degrees of publicity of content and so on (Van Eijk, 2008, p. 1116).

One special feature of the cyberworld is that private companies are so important that they will normally be the main responsible party in matters such as reasonable internet access to the whole population and country, security issues, and so on. At the same time, cybersecurity is an essential component of defence

2 It can entail considerations such as: "The participants did not have an official single view on the issues raised in the public consultation. They mainly raised the need to further assess to which extent price differentials stem from national specificities or from the inconsistent application of costing methodologies and emphasised that any proposed costing methodology should respect the principle of technological neutrality and avoid promoting a particular network roll-out." (Commission Staff Working Document, SWD(2013)329 final, p. 21) 
policy (and law) as well as criminal law and law enforcement, so private firms may find themselves with a major role in the cyberworld that includes issues that are traditional core state policy and governance matters. If the firms do not perform such tasks, they may not be performed at all.

ICT regulation has gone through important changes almost all over the world in recent decades as a consequence of the processes of privatisation, liberalisation and globalisation of the market. What used to be a realm of state-owned and -operated services is now a global market with very important private firms. Privatisation and liberalisation do not have to go hand in hand, as it is possible to have state-owned enterprises operating in a liberalised market, but very often the two phenomena do indeed happen simultaneously. The term privatisation refers to ownership, the property issue, whereas liberalisation refers to what rules are applicable, providing legal conditions for competition (Nihoul \& Rothford, 2004 , p. 83). Competitive elements and an increased role for market forces may be applied at various levels, including in the determination of how radio frequency spectrum should be used. What the combined forces of privatisation and liberalisation have led to is a system in which important public functions to an increasing extent take place on privately operated communications networks. Strategic interests of the state are ensured on privately owned infrastructure, which means that there must be adequate regulatory and licensing tools.

\section{Introductory remarks on the ICT situation in Ukraine}

Ukraine is experiencing a multitude of challenges in the communications sphere - some that it shares with other countries in transition to free expression and rule of law, and some that are specific due to the situation in the country. The Russian annexation of Crimea in 2014 has totally cut off a part of the country from the influence of the Ukrainian legal system or government regulation, illegally subjecting the territory to Russian law. In Eastern Ukraine, Russia's official line has been to claim that it is not (officially) involved but claims that there is an uprising by parts of the population, looking for independence. The rebels who claim to represent popular opinion do not however control the territory sufficiently to implement law. The situation is unclear enough for countries that are looking for an excuse for not taking a firm stance against Russia to be able to point to the conflicting narratives and lack of objective information. This attitude towards Russia among many European (and other) states is not new. Anna Jonsson Cornell in 2011 claimed that EU policy toward Russia was no longer 
value-driven but dictated by realism (Jonsson, 2011, p. 444). The annexation of Crimea was something of a "wake-up call" for those who downplayed the risks from Russia, but quite soon some European states were again looking for excuses for a softer approach toward Russia. Any Ukrainian restrictions on media or communications are used to justify why the picture is not clear and allegations against Russia may not be correct (Nyman Metcalf, 2018, p. 442) Ukraine is going through a period of reform of its communications legislation and regulation, as a result of the general democratisation of the society, at the same time as it is facing the difficulties that the war causes-also for the free flow of information. Situations of war and crisis always provide fertile ground for propaganda as well as attempts to restrict information flows (which may be justified in certain situations). Ukraine, being a country that has been in transition to democracy, but which has not had the opportunity to create strong or well-functioning guarantees for free communications, has to struggle with creating these guarantees in the difficult situation of war. Compared with other Eastern Partnership countries, Ukraine is in the middle of the list regarding media freedom, after Georgia and Moldova but ahead of Armenia, Azerbaijan and Belarus based on monitoring through the EU-funded Eastern Partnership Media Freedom Watch project (published in early 2015). The situation in Eastern Ukraine is much worse than the overall situation in the country ( $E U$ in Ukraine, 2015; Nyman Metcalf, 2018, p. 440). As for availability of ICT, there has been and still is a dependence on Russia (for internet service provision, for example). This anomalous situation would give Russia an advantage in any cyber-attack situation, as Russian firms own infrastructure and even government officials (at least until recently) use Russian email services, as Giles points out (Giles, 2015, p. 24).

The development of communications infrastructure in Ukraine has been fast in some respects but lagging behind in others. Freedom House in their 2018 report state:

Internet penetration continued to grow in 2018. Access to the internet remains affordable for most of the population. The diverse market is no longer dominated by state-owned providers. Inevitably, Ukraine's telecommunications market has suffered due to economic hardships in the country, the crisis following Russia's annexation of Crimea, and the upheaval in eastern Ukraine. (Freedom House 2018)

Ukraine scored 9 out of 25 points, where 0 is the most positive, for internet access. 


\section{The legal situation for ICT in Ukraine}

The rules concerning the regulation of the internet can be found in the general laws. For example, the Law of Ukraine 'On access to public information' describes the principles of publishing and disseminating certain categories of information on the internet, the right to active and passive access of users to information, etc. According to Article 5 of the Law, access to information is ensured by systematic and prompt disclosure of information on official web sites and on a single state web portal of open data. The Law of Ukraine 'On information', dated January 13, 2011, establishes only general rules and guarantees in the field of information legal relations, while not highlighting the peculiarities of regulating the internet.

Important but not complete supplements appeared in the 2017 Law of Ukraine 'On copyright and related rights'. For the first time, at the level of national legislation, the terms 'website', 'web page', 'website owner', 'hyperlink', 'electronic (digital) information', 'account', 'hosting provider' appeared. The new Article 52-1 of the law provides for the possibility of extrajudicial blocking of websites in cases of copyright infringement and the lack of proper response of the website owner to a claim of such violation. In the Criminal Code of Ukraine, the internet is seen as a way of disseminating information (Articles 109, 110). In fact, for law enforcement and the court, there is no difference as to how the 'criminal record' is distributedwhether it will be a distribution of postcards in a crowd, broadcast on radio or TV, a social network post, blog or other online sources.

The question of access to the internet, its use, and especially the restrictions are contained in various legislative acts. In the following context it is important to note that since late 2013, and more intensively since early 2014, Ukraine is at the state of a hybrid war with the Russian Federation, which includes not only physical intrusion and combats but also the informational war in cyberspace. For any country experiencing external military conflict, it is extremely important to find the right balance between protecting human rights (including informational and internet rights), and not to be an easy target for the aggressor, especially when a part of the territory is not under governmental control. This is a challenge that Ukraine and its legal system is currently experiencing (Nyman Metcalf, 2018, p. 445).

The issue behind the regulation of the internet affects a number of relatively recent decrees of the President of Ukraine (Decrees nos. 287/2015, 96/2016, and 47/2017; Government of Ukraine, 2015; 2016; 2017a). These documents detail 
the urgent need for the development of high-quality legislation on cybersecurity and information security of Ukraine and on Russia's aggression against Ukraine, which is also evident online. These decrees establish obligations for the Cabinet of Ministers of Ukraine, specialised law enforcement bodies and scientific institutes to develop necessary legislations.

The Draft Law on Cybersecurity was submitted to the Ukrainian Parliament in 2015. More than two years have passed since the draft was submitted to the Verkhovna Rada, and it came into force only on May 9, 2018. Adoption of the law could take even longer but the Russian virus 'NotPetya', which attacked Ukraine in 2017 (Nakashima, 2018), relatively accelerated the procedure. The virus hit the M.E.Doc accounting program, which is used by companies working with documents of the Ukrainian government. Cybersecurity issues are also regulated by Cyber Security Strategy of Ukraine, the Convention on Cybercrime, the Criminal Code of Ukraine and other normative legal acts. For the first time, the Law on Cybersecurity establishes a significant number of concepts that are new to the legal field of Ukraine such as cybersecurity, cyber-threat, cyberspace, cyber-incident, cyber-espionage, cyberterrorism, etc. Additionally, Article 9 of Law on Cyberspace mentions CERT-UA - a Government Computer Emergency Response Team - and describes its main functions. Its purpose is to protect public information resources and information and telecommunications systems from unauthorised access, misuse, and breaches of their confidentiality, integrity and accessibility.

On October 5, 2015, the Cyber Police was established as a structural unit of the National Police and it is regulated by the Law on National Police from July 2, 2015. The purpose of the Cyber Police in Ukraine is to reform and develop units of the Ministry of Internal Affairs of Ukraine involved in combating cybercrime and capable of applying the latest technologies in operational activities at a professional level. Although the law states that individuals are responsible for breaches of cybersecurity under civil, administrative and criminal law, the codes do not contain any mention of the term 'cyberspace'. This can make it difficult to take responsibility for cybersecurity offenses and this is something that needs additional law-making activities from the parliament. It can be noted that during the past five years, Ukraine has started regulating ITC as well as made the first steps towards cybersecurity development. But the country definitely needs additional work in the field in order to be able to operate in cyberspace and protect itself and its citizens from threats.

Regulation of ICT in Ukraine has a great chance of being improved in the near future due to the 2019 presidential and parliamentary elections as well as some 
governmental appointments. President Zelenskyi's party "Servant of the People" received an absolute majority and declares development towards the "state in a smartphone". The CEO of a digital marketing company SMMSTUDIO Mykhailo Fedorov became the new Vice Prime Minister and Digital Transformation Minister of Ukraine. Also, on August 29, 2019, the founder of Fintech Band and iGOV state digital services initial developer Dmytro Dubilet became a Minister of the Cabinet of Ministers and declares the elimination of paper usage on government and innovations in mechanisms on how the body operates and interacts.

\section{Importance of internet infrastructure in the context of access to information}

Without access to communications infrastructure, there would be no access to content or services. Privately owned communications tools oblige the market to be the main drivers for progress and enhanced access. The nature and significance of the sector have meant that in different parts of the world, different mechanisms have been employed to secure progress and access - the market alone is not enough. ${ }^{3}$ Building up infrastructure - for example, highspeed broadband - should be a policy priority for states and encouraged by various means.

Technological advancements have been continuously generating improved and faster ways to access the internet. For instance, the evolution of the mobile data network between $2 \mathrm{G}, 3 \mathrm{G}$ and $4 \mathrm{G}$ has shown a dramatic increase of the possibility of mobile internet access over the past 25 years (Saraiva Campos, 2017). This has opened up new doors to both public and private services based on ICT. But at the same time, a no less difficult task is the distribution and legal regulation of such technology in each state.

In late 2018 and early 2019, South Korean mobile operators began offering 5G services to their customers. Additionally, on February 20, 2019, Samsung launched the world's first available smartphone with built-in fifth-generation

3 In the EU, there have been efforts since the early 1980s to create a common information area, with a modern information society strategy set out in the Bangemann Report of 1994. Although the report favoured privatisation, liberalisation and market forces, it recognised various areas where intervention would be needed. These were translated into EU policies and regulatory instruments over the years to come. Ways to ensure proper access to communications infrastructure were important elements of the EU rules. (Still, 2010, pp. 338-339) 
communications. It is a matter of time when the economically progressive part of the world and communication companies adjust their infrastructure to follow the contemporary trends. With the development of 5G technology, the world received a new standard of mobile data exchange. $5 \mathrm{G}$ is declared to be 20 times faster compared to 4G. Accordingly, access to this technology will allow even more sophisticated online services in the nearest future.

The importance of communications has meant that the legal regulation of private firms active in this area can be more intrusive than in fields where market forces (almost) alone can be allowed to determine market structures. One feature of ICT regulation is the universal service obligation, which means that firms have to ensure services also in areas where it may not be commercially viable. This will be a prerequisite for being allowed to offer services anywhere, as stipulated in licence conditions. The universal service will either be financed by the firms using profits from other parts of the market, where they may be protected from full competition, or by direct subsidies from a fund that all firms in the sector have to pay into.

The universal service obligation changes the way competition law can be applied and special rules will apply to undertakings given special rights (in the European Union, Article 106 of the Treaty on the Functioning of the EU): competition should be limited only to the extent this is needed given the special nature, such as the universal service obligation. The influence of the universal service obligation should be limited so there is no over-compensation, but compensation for real costs-allowing reasonable profit - for a service that is needed. The promotion of new technologies (digitalisation, for example) may involve state aid, special rights or other measures to influence the market, if necessary.

The idea behind the universal service obligation was to ensure access for all at affordable prices, and quality and availability of the service at all times. This was seen as necessary when ownership of communications services moved to the private sector. The exact content of the universal service obligation has altered over time, as communication habits have changed. It should be used to provide a possibility for reasonable access to what is important at a given time, in a given society. There are now far fewer requirements for public payphones and far more for internet access. Finland became the first country to legislate specifically broadband access: the Law 331/2009 amending the Communications Act stipulates that since July 1, 2010 everyone has the right to broadband of at least 1 megabit, to be increased gradually through ministerial decrees (Still, 2010, p. 342). Despite being advanced when it comes to legislation, there are many critical voices in Finland about how the accessibility to high-speed broadband 
in practice, especially in rural areas, is not well developed (Gustafsson, 2017; Johansson, 2018). This illustrates that legislation alone is not enough.

Mobile and cable internet are the two main means for individuals to access the online world. internet accessibility, as well as Internet affordability, are crucial from a human rights perspective. Recently, Ukraine ranked the 4th out of 230 countries regarding the price of its mobile internet, with data tariffs being cheaper only in India, Kyrgyzstan and Kazakhstan. To compile the ranking, over 6,000 mobile data plans were compared and the average cost of a gigabyte in each country was assessed. The average price for mobile data in Ukraine is 51 cents per gigabyte and the cheapest is 21 cents. For instance, in Portugal the average price for one gigabyte is $\$ 13.98$, which is almost 28 times more expensive in comparison to Ukraine (Cable UK, 2019).

While many people use mobile internet on their smartphones, there are still those who are using home broadband internet. In this case, Ukraine is also in the top-rate statistics. According to Numbeo - a crowd-sourced global database of reported consumer prices - the average monthly internet bill for $60 \mathrm{Mbps}$ or more, Unlimited Data, Cable/ADSL is $\$ 4.57$ as of April 2019. This is almost three times cheaper compared to neighbouring Poland and more than 13 times less expensive when compared to the average similar bill in the USA (Numbeo, 2019). Home broadband internet affordability may be caused by the competition between local providers. For instance, $2 I P$ - a catalogue of Ukrainian internet providers - consists of 1,024 internet providers listed and rated by users $(2 I P$, 2019). Internet connection in Ukraine is one of the most affordable for a hypothetical average citizen in the world. These results may vary slightly if taking into consideration the level of income of each citizen, however, it still remains affordable.

In terms of internet accessibility, there are a few relevant aspects to consider. One of these is broadband speed and whether or not it plays a significant role when it comes to the freedom to connect. According to Fastmetrics (2019), the average speed of broadband connection in Ukraine is $11.2 \mathrm{mbps}$, which compared to other countries ranks in the middle. The next question will be defining the speed of connection that should be supplied to ensure basic human rights. Considering the mobile internet, up until 2015, Ukrainian mobile operators did not provide even $3 \mathrm{G}$ network to their users. From 2015 to 2018, the country moved from 2nd to $3 \mathrm{rd}$ and 4 th generation of mobile internet. Since this information is relatively new, it is difficult to compare Ukrainian level of coverage with the rest of the world. 4G is offered by three main operators: Kyivstar, Vodafone and Lifecell and is covering major cities. Smaller towns and villages are mainly covered 
with $3 \mathrm{G}$ internet. Mobile internet is less accessible in remote areas, mountains and non-controlled territories such as Crimea and parts of Donetsk and Lugansk regions (MobUA, 2019). It would be especially challenging to measure and evaluate mobile penetration in the above-mentioned occupied areas since Russia is trying to provide certain infrastructure in these locations.

It is also important to mention that anyone in Ukraine can buy most sim-cards and mobile plans in authorised stores without an ID or any other personal identification documents. This mode of connectivity applies to foreigners as well. Considering this fact, internet in Ukraine is on average quite accessible and very much affordable from the global perspective of human rights. Additionally, if the government together with telecom providers manage to speed up $4 \mathrm{G}$ network development, the country could possibly become one of the best in the world in terms of coverage/price balance.

\section{Concluding remarks}

Freedom of expression is usually approached from the angle of content or expression: is there freedom to say whatever one wants and freedom to access expressions of different kind? In an era where expressions were direct 'human-tohuman' ones or delivered by technologically relatively non-complicated means, such as printed text, the legal issues indeed normally concerned only whether certain content would be prohibited or sanctioned. With the development of technology, we can observe how the legal system has had to devote attention also to physical and technical access to the means of communication, from rules for radio frequency allocation to licensing for broadcasters, leading on to access to internet and in the future probably to ways to use whatever even more modern channels for communication will appear. This change in focus entailed many changes for the legal content of protection of freedom of expression, which, as we have discussed, includes infrastructure issues with aspects of competition law, state investments and other such matters that may not at first glance appear to have much to do with freedom of expression.

There is no question about internet access being a relevant component of freedom of expression, given how widespread the internet is and what a large part of daily communication happens on this medium. What this means more specifically when assessing the importance of internet in a specific country is that one has to look at a combination of legislation on internet content, legislation and regulation of internet firms, actual accessibility and availability-including 
affordability — of the internet. All these components together help to answer the question of what the situation really is like. We used Ukraine as the example against which to evaluate such matters.

Ukraine is still in transition to become a fully functioning rule-of-law state with strong protection for human rights, such as freedom of expression, also for market participants. However, in some areas related to the accessibility of communication for people, Ukraine scores very well. This has been achieved by a combination of legislation, regulation, and market forces. The country presents an interesting illustration of the mosaic of factors that lead to a good communications landscape; something that cannot be built neither by legislation nor by the market alone.

Bogdan Kelichavyi is currently working as a Local Economic Development Officer for USAID/DOBRE project supporting 75 amalgamated communities in Ukraine. He received two master's degrees from TalTech in 2016, specializing in international law and e-governance. Concentrating his attention on small municipalities' development around the world, Kelichavyi is convinced that freedom of expression and internet access are crucial for local communities to achieve sustainable development.

Katrin Nyman Metcalf is an adjunct professor of communications law at the Institute of Law, Tallinn University of Technology, and programme director for research and legal issues at the Estonian e-Governance Academy. She furthermore works globally as a consultant on e-governance as well as communications law related issues (ICT, freedom of expression, internet, data protection, etc.).

\section{References}

2IP (2019), [Home page]. Retrieved from https://2ip.me/en/ [accessed 13 Apr 2019] Access Now (2019), 'Changes to Australia's criminal code will create a new class of internet censorship,' 2 April. Retrieved from_https://www.accessnow.org/changesto-australias-criminal-code-will-create-a-new-class-of-internet-censorship [accessed 14 Apr 2019]

Altmark Trans GmbH and Regierungspräsidium Magdeburg v. Nahverkehrsgesellschaft Altmark GmbH, and Oberbundesanwalt beim Bundesverwaltungsgericht [2000], European Court of Justice, C-280/00. 
Burlyuk, O. (2015), 'The introduction and consolidation of the rule of law in Ukraine: domestic hindrances at the level of the demand for law, Hague Journal on Rule of Law, vol. 7, no. 1, pp. 1-25. https://doi.org/10.1007/s40803-015-0001-y

Cable UK (2019), 'Worldwide data pricing.' Retrieved from https://www.cable.co.uk/ mobiles/worldwide-data-pricing/?fbclid=IwAR3HVmdI7Kd1QRn2RvoVe6yVIY iSLu7nc2DjRt_oRS5duIgOkAiVmtsa-s0 [accessed 13 Apr 2019]

Commission Staff Working Document SWD(2013) 329 final: Impact Assessment, Accompanying the document Commission Recommendation on consistent nondiscrimination obligations and costing methodologies to promote competition and enhance the broadband investment environment, 11.9.2013.

Communication COM(1999) 539 from the Commission to the Council, the European Parliament, the Economic and Social Committee and the Committee of the Regions, Towards a new framework for Electronic Communications infrastructure and associated services, 10.11.1999.

Corbeau [1991], European Court of Justice, C-320/91.

De Muyter, L. (2012), 'Regulatory asymmetry? The competition between telecommunication operators and other ICT players,' Journal of European Competition Law \& Practice, vol. 3, no. 5, pp. 452-464.

https://doi.org/10.1093/jeclap/lps045

EU in Ukraine (2015), 'Media freedom index: Georgia leads Eastern Partnership countries,' Cooperation News. Retrieved from http://euukrainecoop. com/2015/02/25/media/ [accessed 14 Apr 2019]

European Convention on Human Rights (1952), 4 November 1950 CETS 005, in force 3 September 1953. Retrieved from http://www.conventions.coe.int/Treaty/ [accessed Nov 2019]

Fastmetrics (2019), 'Internet speeds by country (Mbps).' Retrieved from https://www. fastmetrics.com/internet-connection-speed-by-country.php [accessed $13 \mathrm{Apr}$ 2019]

Forbes Russia (2014), 'Durov obiasnil prodazhu doli vo "VKontakte" konfliktom s FSB' [Durov explained the conflict with the FSB regarding the sale of VKontakte shares], 17 April. Retrieved from https://www.forbes.ru/news/255173-durovobyasnil-prodazhu-doli-vo-vkontakte-konfliktom-s-fsb [accessed 13 Apr 2019]

Freedom House (2018), 'Freedom on the Net 2018.' Retrieved from https://freedomhouse. org/report/freedom-net/2018/ukraine [accessed 13 Apr 2019]

Giles, K. (2015), 'Russia and its neighbours: old attitudes, new capabilities,' in K. Geers (ed.) Cyber War in Perspective: Russian Aggression against Ukraine, Tallinn: NATO Cooperative Cyber Defence Centre of Excellence, pp. 19-28.

Government of Ukraine (2015), Decree of the President of Ukraine no. 878, 'On the decision of the National Security and Defense Council of Ukraine,' 26.5.2015; 'On the strategy of National Security of Ukraine,' 6.5.2015. 
Government of Ukraine (2016), Presidential Decree no. 96/2016 'On the decision of the National Security and Defense Council of Ukraine,'27.1.2016; 'On the strategy of cybersecurity of Ukraine,' 27.01.2016.

Government of Ukraine (2017a), Decree of the President of Ukraine no. 47/2017 'On decision of the Council of National Security and Defense of Ukraine,' 29.12.2016; 'On the doctrine of information security of Ukraine,' 29.12.2016.

Government of Ukraine (2017b), Decree of the President of Ukraine no. 133/2017 'On the decision of the National Security and Defense Council of Ukraine,' 28.4.2017; 'On the application of personal special economic and other restrictive measures (sanctions),' 28.4.2017.

Gustafsson, L. (2017), 'Telebolag vill ha supersnabbt bredband för alla finländare,' Svenska YLE, 6 June. Retrieved from https://svenska.yle.fi/artikel/2017/06/06/ telebolag-vill-ha-supersnabbt-bredband-alla-finlandare [accessed 13 Apr 2019]

Habermas, J. (1991), The Structural Transformation of the Public Sphere. An Inquiry into a Category of Bourgeois Society, Cambridge, MA: The MIT Press.

Harrison, J. \& Woods, L. (2007), European Broadcasting Law and Policy, Cambridge: Cambridge University Press. https://doi.org/10.1017/CBO9780511495298

Johansson, K. (2018), 'Finland näst sämst i EU på bredband på glesbygden,' Svenska $Y L E, 5$ April. Retrieved from https://svenska.yle.fi/artikel/2018/04/05/finlandnast-samst-i-eu-pa-bredband-pa-glesbygden [accessed 13 Apr 2019]

Jonsson, A. (2011), 'Russia and Europe,' in G. Gill \& J. Young (eds.) Routledge Handbook of Russian Politics and Society, London: Routledge, pp. 444-453.

Kamecke, U. \& Körber, T. (2008), 'Technological neutrality in the EC regulatory framework for electronic communications: a good principle widely misunderstood,' European Competition Law Review, no. 5, pp. 330-337.

MobUA (2019), 'Maps.' Retrieved from https://www.mobua.net/maps/?pos= 49.339081,26.315016,7 [accessed 13 Apr 2019]

Nakashima, E. (2018), 'Russian military was behind 'NotPetya' cyberattack in Ukraine, CIA concludes,' The Washington Post, 13 January. Retrieved from https://www. washingtonpost.com/world/national-security/russian-military-was-behindnotpetya-cyberattack-in-ukraine-cia-concludes/2018/01/12/048d8506-f7ca-11e7b34a-b85626af34ef_story.html?noredirect=on [accessed 7 Sep 2019]

Nihoul, P. \& Rothford, P. (2004), EU Electronic Communications Law. Competition and Regulation in the European Telecommunications Market, Oxford: Oxford University Press.

Nikolinakos, N. Th. (2006), EU Competition Law and Regulation in the Converging Telecommunications, Media and IT Sectors, Alphen aan den Rijn: Kluwer Law International.

Numbeo (2019), 'Prices by country of internet (60 Mbps or more, unlimited data, cable/ ADSL) (Utilities (monthly)),' Retrieved from https://www.numbeo.com/cost-of- 
living/prices_by_country.jsp?displayCurrency=USD\&itemId=33 [accessed 13 Apr 2019]

Nyman Metcalf, K. (2018), 'Post-conflict reconstruction of trust in media,' in S. Sayapin \& E. Tsybuluneko (eds.) The Use of Force against Ukraine and International Law, The Hague: Springer, pp. 425-445.

https://doi.org/10.1007/978-94-6265-222-4_20

Saraiva Campos, R. (2017), 'Evolution of positioning techniques in cellular networks, from 2G to 4G,' Wireless Communications and Mobile Computing, vol. 2017, Article ID 2315036. https://doi.org/10.1155/2017/2315036.

Schwarz, T.; Satola, D. \& Bustani, C. (2001), 'Telecommunications reform in emerging markets,' in I. Walden \& J. Angel (eds.) Telecommunications Law, London: Blackstone Press, pp. 488-529.

Still, V. (2010), 'Free movement of information,' Scandinavian Studies in Law: ICT Legal Issues, vol. 56, pp. 329-358.

The Bell (2018), 'Pavel Durov_biografiia, sostoianie, "VKontakte” i Telegram' [Pavel Durov-biography, situation, VKontakte and Telegram], 17 December. Retrieved from https://thebell.io/pavel-durov-biografiya-sostoyanie-vkontakte-i-telegram/ [accessed 13 Apr 2019]

Universal Covenant on Civil and Political Rights (1966), UNTS 999, United Nations, 16.12.1966. Retrieved from http://treaties.un.org/ [accessed Nov 2019]

Van Eijk, N. (2008), 'The new European framework for the communications sector,' in O. Castendyk, E. Dommering \& A. Scheuer (eds.) European Media Law, Alphen aan den Rijn: Wolters Kluwer, pp. 1109-1125. 